\title{
The Effectiveness of Pamanpintermu E-reading Program on EFL Learners' Reading Performances
}

\author{
Yudhi Arifani \\ University of Muhammadiyah Gresik \\ yudhi_arif@umg.ac.id
}

\begin{abstract}
This study investigated the effectiveness of using Pamanpintermu e-reading program on English Foreign Language Learners' (EFLL) reading performances. The participants were 64 first-year senior high school students who belonged to intermediate level of English that one exemplary public senior high school in Gresik, Indonesia. During the semester experiment, students read the texts, wrote vocabulary survey tasks, inputted their timed reading, and answered reading comprehension exercises from the Pamanpintermu e-reading program. The result of t-tests revealed significant difference between the students who were taught using Pamanpintermu e-reading program and those that were taught using traditional reading regarding its rate, vocabulary, and comprehension but it was no significant difference about their reading error. However, the qualitative data furnished several insights why Pamanpintermu e-reading program make a difference. Suggestions to improve the forthcoming e-reading program can serve as a model to incorporate between mobile e-reading applications and EFL curriculum is worth contributing.
\end{abstract}

Keywords: Pamanpintermu e-reading program, reading performance, EFL learners

\section{INTRODUCTION}

The vast development of digital technology has attracted researchers and teachers to utilize to use of mobile technology in English language reading class. Many aspects of mobile device in English language reading contexts such as types, roles, and effects of the mobile device both off line and online format on reading practices have been portrayed[1-9].The term Pamanpintermu e-reading program in this article refers to reading passage/text presented in an electronic format that allows teachers and students to read, create their own reading within the device through offline model. It of fersvarious merits because the users just need to install the device into their gadgets without any internet connections. It also functionsas students' individual reading performance assessment to measure their vocabulary development, fluency, speed and comprehension.

Several research eshave investigated largely on the use of mobile devices for reading program with numerous type of famous mobile device attributes[10, 11].For example, [11] studied the students' reading comprehension and satisfaction toward the students who were taught using learner-centered mobile learning instruction versus teacher-centered without mobile learning.[3] investigated the use of computer assisted language learning in the form of PDAs to elaborate students' attitude and respond toward the mobile system.

Previous studies concern primarily on the use of different kinds of mobile devices in reading class with the aims to identify various types of devices used, impact on students' reading perceptions, attitudes, motivation and comprehension. Fairly less attention, however, has been focused on both teachers and students' perspective toward mobile devices through online format. Furthermore, no researchers investigate on reading mobile devices through offline formats which can be modified autonomously by EFL teachers and learners so that sensitive issues like internet connection, text difficulty level, curriculum suitability and students' learning needs could be more wisely well-addressed. Consequently, the objectives of this study aim to explore the effects of using Pamanpintermu e-reading program toward EFL learners reading performances

\section{METHOD}

This study was conductedin an exemplary public senior high school inGresik, East Java, Indonesia. This study aimed to investigate the effectiveness of Pamanpintermue-reading program toward students' reading performance and their suggestion toward the project future integration with EFL curriculum.Two EFL classesof tenth grade students participated in this experimental inquiry forten weeks experiment with64students (29 males and 35 females)from one public senior high school was given and installed the software of Pamanpintermu e-reading program to their gadgets such as laptop, mobile phones and tablets. During the ten weeks experiment, students did vocabulary survey task, read timed reading section, identified their reading errors, did comprehension questions, and submitted their overall reading 
performance from the application to their English teachers. The participants consist of fifty-sixfirst grade senior high school's students (29males and35 females) from an exemplary public senior high school. They had all learned English approximately for 6 years where 3 years were obtained from their elementary and 3 years acquired from their junior high school. The institutional TOEFL score was administered with the average score of398 with the lowest score was 369 and the highest score was 457. Aside of the TOEFL score, the English teacher and school principal assured the researcher that every attempt was made to make the class as homogeneous as possible. Additional speed reading and error reading test were made using reading passage section from the TOEFL test with around 250-300 words number. In this case, four teachers from experimental group assessed 32 students' reading speed and errors. It did similarly towards the control group. Before the experiment began, Pamanpintermu e-reading application was installed to 32 students' laptops in the experimental group. Next, they were explained the rationale for this project and they were asked to create their own user name and password to run the application. The students were also introduced the contents of the ereading application clearly so that they could run it independently. For ten weeks experiment, all students were required to fill out one vocabulary survey question which has top ten answer scores (each answer spent 20 seconds).

Afterward, the students were asked to continue reading fluency and speed section. When the reading passage toolbar was tapped, the text was displayed and the timer counted down automatically. Therefore, the students had to read the passage fluently and quickly. As the reading error detector menu was not perfect yet, so the students had to be honest in identifying, computing and inputting the number of reading errors they made into the application bar. A dictionary from reading text named as Di-Text was provided to help students check whether their pronunciation was correct or not. The last step, students were required to answer ten multiple choice format questions for comprehension check in limited time.

In pre-test and post-test, students' pronunciation errors were assessed by the teachers in the schools. Four teachers in the experimental group school assessed 32 students' reading error and other four teachers from control group school did the same. Consequently, every teacher had to assess at least 8 students. Several reading texts for approximately 250-300 words from TOEFL test were designed to assess students' reading errors and speed.

For each quantitative data, pre-test and post-test on students' reading performance (vocabulary, fluency, speed and comprehension) were collected and computed using descriptive statistics which include means and standard deviations.
Table 1 . Normality tests reading performance

\begin{tabular}{llcccccc}
\hline & \multirow{2}{*}{ Group } & \multicolumn{3}{c}{ Kolmogorov-smirnov $^{\mathrm{a}}$} & \multicolumn{3}{c}{ Shapiro-wilk } \\
\cline { 2 - 8 } & Statistic & Df & Sig. & Statistic & df & Sig. \\
\hline $\begin{array}{l}\text { Reading } \\
\text { performanc } \\
\text { e }\end{array}$ & $\begin{array}{l}\text { Pamanpintermu } \\
\text { e-reading }\end{array}$ & .119 & 32 & $.200^{*}$ & .958 & 32 & .243 \\
\cline { 2 - 8 } & $\begin{array}{l}\text { Traditional } \\
\text { reading }\end{array}$ & .152 & 32 & .057 & .949 & 32 & .139 \\
\hline
\end{tabular}

*Significant at $p<.05$.

Table 2. Levene's test of equality of error variancesa

\begin{tabular}{cccc}
\hline $\mathrm{F}$ & $\mathrm{df1}$ & $\mathrm{df} 2$ & Sig. \\
\hline .090 & 1 & 62 & .765 \\
\hline *Significant at $p<.05$. & &
\end{tabular}

\section{RESULT}

Normality and homogeneity tests on students' reading performance were calculated Table 1 and Table 2). The independent variable was the use of Pamanpintermu e-reading program and dependent variables were the gains from pretest to posttest in reading rate, reading error, vocabulary and reading comprehension. The results of normality and homogeneity of the two groups reading performance were not violated $(p=.200$ and $p=.057)$. Levene's tests indicated the assumption of equality of variance was not violated $(p=.765)$.

Research question 1: What is the difference in students' reading error between those using Pamanpintermu e-reading program and those students not using Pamanpintermu e-reading program?

The data from reading error test was used (Table 3). The Pamanpintermu e-reading intervention group participants' reading error had similar gain in their mean scores $(\mathrm{M}=2.7 ; \mathrm{SD}=1.39)$ with the traditional reading scores $(\mathrm{M}=2.9$; $\mathrm{SD}=.33)$. Both Pamanpintermu ereading and traditional reading had a very similar positive gain in reading error. However, the independent sample test showed that the differences were not statistically significant $(p=.64)$. Consequently, there were no significant differences of reading error scores between the students' who were taught using Pamanpintermu e-reading and those students who were taught using the traditional reading.

Table 3. Means and standard deviations for Pamanpintermu e-reading and traditional reading error

\begin{tabular}{llccc}
\hline & Group & Mean & $\begin{array}{c}\text { Std. } \\
\text { deviation }\end{array}$ & $\begin{array}{c}\text { Std. error } \\
\text { mean }\end{array}$ \\
\hline $\begin{array}{l}\text { Reading } \\
\text { error }\end{array}$ & $\begin{array}{l}\text { Pamanpintermue- } \\
\text { reading }\end{array}$ & 2.7576 & 1.39262 & .24242 \\
& $\begin{array}{l}\text { Traditional } \\
\text { reading }\end{array}$ & 2.9394 & 1.73096 & .30132 \\
& & & & \\
\hline
\end{tabular}


Research question 2: What is the difference in students' vocabulary between those using Pamanpintermu e-reading program and those students not using Pamanpintermu e-reading program?

The data from vocabulary reading test was used (Table 4). The Pamanpintermu e-reading intervention group participants' vocabulary score had higher gains in their mean scores $(\mathrm{M}=69.9 ; \mathrm{SD}=5.4)$ than the traditional reading scores $(\mathrm{M}=66.1 ; \mathrm{SD}=6.7)$. The independent sample test showed that the differences were statistically significant $(p=.01)$. As a result, there were significant differences in vocabulary scores between the students' who were taught using Pamanpintermuereading and those students who were taught using traditional reading.

Research question 3: What is the difference in students' reading comprehension between those using Pamanpintermu e-reading program and those students not using Pamanpintermu e-reading program?

The data from reading test comprehension was used (Table 5).ThePamanpintermu e-reading intervention group participants' reading comprehension score had higher gains in their mean scores $(\mathrm{M}=70.3 ; \mathrm{SD}=$ 5.5)than the traditional reading scores $(\mathrm{M}=66.7$; $\mathrm{SD}=$ 6.6). The independent sample test showed that the differences were statistically significant $(p=.02)$. Therefore, there were significant differences in reading comprehension scores between the students' who were taught using Pamanpintermue-reading and those students who were taught using traditional reading.

The effectiveness of Pamanpintermu e-reading program on EFL learners' reading performance was reflected in students' reading rate, vocabulary, and comprehension.

Table 4. Means and standard deviations for Pamanpintermu e-reading and traditional vocabulary

\begin{tabular}{clcccc}
\hline \multicolumn{1}{c}{ Group } & $\mathrm{N}$ & Mean & $\mathrm{SD}$ & $\mathrm{SE}$ \\
\hline Vocabulary & $\begin{array}{l}\text { Pamanpintermu } \\
\text { e-reading }\end{array}$ & 33 & 69.93 & 5.41 & .94 \\
$\begin{array}{l}\text { Traditional } \\
\text { reading }\end{array}$ & 33 & 66.12 & 6.70 & 1.16 \\
\hline
\end{tabular}

Table 5. Means and standard deviations Pamanpintermu e-reading and traditional reading comprehension

\begin{tabular}{llcccr}
\hline \multicolumn{1}{c}{ Group } & $\mathrm{N}$ & $\mathrm{M}$ & $\mathrm{SD}$ & $\mathrm{SE}$ \\
\hline $\begin{array}{l}\text { Reading } \\
\text { comprehension }\end{array}$ & $\begin{array}{l}\text { Pamanpinterm } \\
\text { u e-reading } \\
\begin{array}{l}\text { Traditional } \\
\text { reading }\end{array}\end{array}$ & 33 & 70.30 & 5.54 & .96 \\
& 336.72 & 6.69 & 1.16 \\
\hline
\end{tabular}

Overall, students' reading rate, vocabulary, and comprehension that were taught using Pamanpintermu ereading had higher gain score than those students who were taught using traditional reading. Meanwhile, there were no significant differences in reading errors between the two groups. This phenomenon reveals that the students who learn reading via Pamanpintermue-reading tends to acquire more vocabulary and perform better in reading comprehension with lower reading rate or faster than those students who learn through traditional reading. First, the lower adding rate in reading the passage occurs because timer in the application obliges them to read the passage and accomplishes their tasks within the determined time unless the application will automatically close when the time is over. That is why they neglect their reading fluency so that they did not pay attention to their reading errors and what important to them is the ability to comprehend the text as fast as possible. For them, finding the main idea of the paragraph, skimming and scanning while they are reading seem to be more dominant strategy during time reading. Contrary, when the students read novel or short story for example they look to be more pleasure to read every word in the printed reading texts. Eyestrain seems to be another hamper in reading through technology as they shouldread for longer period. Besides, the finding of reading rate or speed reading also corroborates other previous studies [12-14] and [15] claimed that fluency is determinant factor in supporting students' reading comprehension.

The other function of Pamanpintermu e-reading favored by the students was the audio dictionary text. The students liked this menu to develop their reading fluency and vocabulary. When they did not know the meaning of the unfamiliar words from the text and did not know how to say the words, dictionary text become stheir swift solution. The result of the finding confirms[16]assertion that electronic vocabulary or glossary on unfamiliar words can support students' reading comprehension.

The audio-reading functions in Pamanpintermu ereading application were considered very supportive in developing students' listening and reading skills.This finding also confirms [17] that audio reading or listening to the passage helps language input more comprehensible and it also establishes students' motivation. Further, [17] showed that the effect of audio in e-book increase students' motivation in reading. This study also supports [17]study.

\section{CONCLUSION}

In conclusion, effective learning and innovations in mobile technology should be flexible, modifiable and arouse EFL teachers and researchers to facilitate effective learning. If other previous studies have utilized instant teaching application, this study provides different insight where EFL teachers and learners can create their own learning material using Pamanpintermu application. This study also provides empirical evidence on how modifiable Pamanpintermue-reading program could improve students' reading rate, vocabulary, and comprehension. So, even though this was a small study, but it does add the body of research that supports EFL teachers in teaching and learning reading. For future research, a qualitative analysis on the use of Pamanpintermue-reading program with in depth observations will shed new insight on how EFL teachers create their own reading performance materials as well as implementing it in EFL classroom reading and curricula in the future. 


\section{REFERENCE}

[1] M. Alemi, A. Sarab, and Z. Lari, "Successful learning of academic word list via MALL: mobile assisted language learning," nternational Education Studies, vol. 5, pp. 99-109, 2012.

[2] H. Azman, A. Bhooth, and K. Ismail, "Readers reading practices of EFL Yemeni students: recommendations for the 21st century," GEMA: Online Journal of Language Studies, vol. 13, pp. 63-78, 2013.

[3] C.-K. Chang and C.-K. Hsu, "A mobile-assisted synchronously collaborative translationannotation system for English as a foreign language (EFL) reading comprehension," Computer Assisted Language Learning Journal, vol. 24, pp. 155-180, 2011.

[4] C.-M. Chen and S.-H. Hsu, "Personalized intelligent mobile learning system for supportive effective English learning," Educational Technology and Society, vol. 11, pp. 153-180, 2008.

[5] N. Hazaea and A. Alzubi, "The effectiveness of using mobile on EFL learners' reading practices in Najran University," English Language Teaching, vol. 9, pp. 8-21, 2016.

[6] L. Hsu, "English foreign language learners' perception of mobile assisted language learning: a cross-national study," Computer Assisted Language Learning Journal, vol. 26, pp. 258-281, 2012.

[7] A. Kukulska-Hulme and L. Shield, "An overview of mobile assisted language learning: from content delivery to supported collaboration and interaction," ReCALL, vol. 20, pp. 271-289, 2008.

[8] Y. Lan, Y. Sung, and K. Chang, "Let us read together: development and evaluation of a computer-assisted reciprocal early English reading system," Computers \& Education, vol. 53, pp. 1188-1198, 2009.

[9] T. Wu, T. Sung, Y. Huang, C. Yang, and J. Yang, "Ubiquitous English learning system with dynamic personalized guidance of learning portfolio," Journal of Educational Technology \& Society, vol. 14, pp. 164-180, 2011.

[10] D. Yakut and S. Aydin, "An experimental study on the use of blogs on EFL reading comprehension," Innovation in Language Learning and Teaching, vol. 11, pp. 1-16, 2017.

[11] Y. Wang, "Integrating self-paced mobile learning into language instruction: impact on reading comprehension and learner satisfaction," Interactive Learning Environments, vol. 25, pp. 397-411, 2015.

[12] N. Duke, K. Cartwright, and K. Hilden, Difficulties in reading comprehension. New York: Guilford, 2004.

[13] T. Myers, "The relationship between fluency and comprehension," Goucher College, Baltimore2015.

[14] N. Padak and T. Rasinski, Fast starts for early readers a research based, send-home literacy program. New York: Scholastic US, 2005.

[15] T. Rasisnski, S. Homan, and M. Biggs, "Teaching reading fluency to struggling readers: Method, materials, and evidence," Reading and Writing Quarterly, vol. 25, pp. 192-204, 2009.

[16] O. Lenders, "Electronic glossing-is it worth the effort," Computer Assisted Language Learning, vol. 21, pp. 457-481, 2008.

[17] I.-j. Lin, "The effects of e-books on EFL learners' reading attitude," National Taiwan Normal University, Taipei, Taiwan2009. 